Minh. 2014; 6 (S18) : 664 - 668.

2. Altena $E$, Baglioni $C$, Espie C, et al. Dealing with Sleep Problems During Home Confinement Due to the Covid-19 Outbreak: Practical Recommendations from A Task Force of the European CBT-I Academy. J. Sleep Res. 2020 Aug; 29(4): e13052. doi: 10.1111/jsr.13052.

3. Daniel J.Buysse, Charles F.ReynoldsIII, Timothy H.Monk, Susan R.Berman, David J.Kupfer. The Pittsburgh sleep quality index: A new instrument for psychiatric practice and research, Psychiatry Research. 1989; 28(2): 193-213.

4. Grimaldi-Puyana, Moisés; FernándezBatanero, José M.; Fennell, Curtis; Sañudo, Borja. 2020. Associations of Objectively-Assessed Smartphone Use with Physical Activity, Sedentary Behavior, Mood, and Sleep Quality in Young Adults: A Cross-Sectional Study Int. J. Environ. Res. Public Health 17(10): 3499. https://doi.org/ 10.3390/ ijerph17103499

5. Hindmarch I, Rigney U, Stanley $N$, Quinlan $P$, Rycroft J, Lane J. A naturalistic investigation of the effects of day-long consumption of tea, coffee and water on alertness, sleep onset and sleep quality. Psychopharmacology (Berl). 2000 Apr: 149(3): 203-16. doi:10.1007/s002130000383. PMID: 10823400.

6. Ranjbar $K$, Hosseinpour $H$, Shahriarirad $R$, et al. Students' attitude and sleep pattern during school closure following COVID-19 pandemic quarantine: a web-based survey in south of Iran. Environ Health Prev Med. 2021 Mar 10; 26(1):33. doi: $10.1186 /$ s12199-021-00950-4.

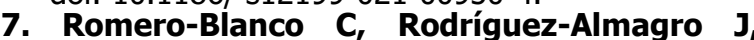
Onieva-Zafra MD, et al. Sleep Pattern Changes in Nursing Students during the COVID-19 Lockdown. Int J Environ Res Public Health. 2020 Jul 20; 17(14): 5222. doi: 10.3390

8. Sañudo B, Fennell C, Sánchez-Oliver AJ, et al. Objectively Assessed Physical Activity, Sedentary Behavior, Smartphone Use, and Sleep Patterns Pre- and during COVID-19 Quarantine in Young Adults from Spain. Sustainability. 2020; 12(15): 5890. https://doi.org/ 10.3390/su12155890.

\title{
ĐÁNH GIÁ ĐôC TÍNH CẤP TÍNH CỦA CAO CHIẾT HẠT CÀ PHÊ XANH VIẸTT NAM TRÊN ĐộNG VẬT THỰC NGHIỆM
}

\section{TÓM TẮT}

Mục tiêu: Đánh giá độc tính cấp tính của cao chiết hat cà phê xanh Viêt Nam trên chuột nhắt trắng. Phương pháp: Độc tính cấp tính được đánh giá qua 2 pha: Pha dò liều và pha đánh giá. Pha dò liều đước thực hiện với mỗi liều 2 chuột nhắt để tìm ra liều gẩy chết 1 trong 2 chuột. Pha đánh giá được thực hiện nhằm xác định liều LD50 với các liều lấy cơ sở từ pha dò liều. Các dấu hiệu nhiễm độc của chuột hoặc chuột chết ở cả hai pha đều được theo dõi trong 72 giờ sau khi uống cao chiết hạt cà phê xanh. Kết quả: Ở pha dò liều: với liêu $5000 \mathrm{mg} / \mathrm{kg}$ vẫn không làm chết 1 trong 2 chuột được thứ nghiệm. Ở pha đánh giá, trong 72 giờ theo dõi, không thãy có dấu hiệu nhiềm độc ở chuột và không có chuột chết, trọng lượng chuột không bị giảm, hình ảnh vì thể của gan và thận của chuột hoàn toàn bình thường ở tất cả các liều cao chiết thử nghiệm là $500 \mathrm{mg} / \mathrm{kg}, 1000 \mathrm{mg} / \mathrm{kg}$, $2000 \mathrm{mg} / \mathrm{kg}$ và $5000 \mathrm{mg} / \mathrm{kg}$. Kêt luận: Cao chiết hạt cà phê xanh là an toàn. Liệu độc tính LD50 của cao chiết hạt cà phê xanh là lớn hơn $5000 \mathrm{mg} / \mathrm{kg}$.

Tư khóa: Độc tính cấp tính, cao chiết hạt cà phê xanh Việt Nam, chuột nhắt.

${ }^{1}$ Học viện Quân y

2'Bệnh viện TUQQĐ 108

Chịu trách nhiệm chính: Lê Văn Quân

Email: levanquan2002@yahoo.com

Ngày nhận bài: 15/9/2021

Ngày phản biên khoa hoc: 5/10/2021

Ngày duyệt bài: 2/11/2021

\section{Lê Văn Quân ${ }^{1}$, Cấn Văn Mão ${ }^{1}$, Nguyễn Việt $\mathrm{Nam}^{2}$, Nguyễn Trọng Nghĩa ${ }^{2}$}

\section{SUMMARY}

ACUTE TOXICITY OF THE VIETNEM GREEN COFFEE BEAN EXTRACT IN EXPERIMENTAL

\section{ANIMALS}

Objective: To assses acute toxicity of the Vietnam green coffee bean extract in mice. Methods: The acute toxicity of the product was evaluated through 2 phases: limited test and main test. In the limited test, 2 animals were administrated for each dose in series doses to find the dose in which 01 of 2 animals dead. From this dose, in the main test, series doses were contributed to series animal groups to measure LD50. Toxic symptoms or deaths in amimals were observed within 72 hours. Results: In the limited test, at dose $5000 \mathrm{mg} / \mathrm{kg}$, both animals were not dead with 72 hours. In the main test, within 72 hours, toxic symptoms or deaths in animals were not found. Body weights of all animals were not decreased. Histological images of livers and kidneys in all animals were normal at all series doses including $500 \mathrm{mg} / \mathrm{kg}, 1000 \mathrm{mg} / \mathrm{kg}, 2000 \mathrm{mg} / \mathrm{kg}$ and $5000 \mathrm{mg} / \mathrm{kg}$. Conclusion: The Vietnam green coffee bean extracts, LD50 of this product was higher than $5000 \mathrm{mg} / \mathrm{kg}$.

Keywords: Acute toxicity, Vietnam green coffee bean extract, mice

\section{I. ĐĂT VẤN ĐỀ}

Béo phì, rối loạn chuyển hóa lipid đang có xu hướng tăng, đặc biệt là ở các nước đang phát triển và phát triển. Tại Mỹ, theo ước tính có khoảng hơn 100 triệu người Mỹ, chiếm khoảng 
53\% người lớn có biểu hiện tăng cholesterol-LDL [1] và khoảng hơn 31 triệu người Mỹ trưởng thành có tăng nồng độ cholesterol toàn phần ở múc trên $240 \mathrm{mg} / \mathrm{dl}$ [2]. Tại Việt Nam, Việt Nam có tới 30\% người trưởng thành bị mắc bệnh mõ máu (rối loạn lipid máu), tỷ lệ người thành thị mắc bệnh là 44,3\%. Số người bị bệnh ngày càng gia tăng, đặc biệt ở những người trẻ tuổi [3]. Tình trạng tăng lipid máu là yếu tố nguy cơ của rất nhiều bệnh lý, đặc biệt là các bệnh tim mạch như vữa xơ động mạch, tăng huyết áp ... Vì vậy, phát hiện sớm và điều trị triệt để là yếu tố quan trọng nhằm hạn chế các biến chứng và gánh nặng bệnh tật cho xã hội. Trong các nghiên cứu gần đây, người ta đã chứng minh cao chiết hạt cà phê xanh có hiệu quả rõ rệt trong giảm cân, chống rối loạn lipid máu. Với sự phân bố khá lớn của cây cà phê ở Việt Nam thì cao chiết hạt cà phê xanh có thể là nguồn dược liệu tốt cho ứng dụng điều trị chống rối loạn lipid trên lâm sàng tại Việt Nam. Để làm cơ sở cho sự phát triển loại dược liệu này, đánh giá tính an toàn khi được sử dụng là hết sức cần thiết. Vì vậy, chúng tôi tiến hành nghiên cứu này nhằm mục tiêu: Đánh giá độc tính cấp tính thông qua xác định liều độc tính LD50 của cao chiết hạt cà phê xanh trên thực nghiệm.

\section{II. ĐỐI TƯỢNG VÀ PHƯƠNG PHÁP NGHIÊN CỨU}

2.1. Đối tượng nghiên cứu. Chuột nhắt trắng chủng Swiss khỏe mạnh được sử dụng trong nghiên cứu này. Chuột được nuôi trong điều kiện thoáng mát, chu kỳ sáng/tối là 12 giờ với thức ăn và nước uống không bị giới hạn. Chuột được nhịn ăn 12 giờ trước khi cho uống thuốc. Tất cả qui trình thí nghiệm tuân thủ chặt chẽ theo hướng dẫn chăm sóc và sử dụng động vật trong thí nghiệm.

\subsection{Phương pháp nghiên cứu}

2.2.1. Pha dò liều. Đầu tiên, cao chiết hạt cà phê xanh được cho 2 chuột uống với liều duy nhất là $2000 \mathrm{mg} / \mathrm{kg}$. Theo dõi chuột trong 3-4 giờ một lần trong 72 giờ đầu. Vì hai chuột này không chết, nên tiếp tục cho 2 chuột khác uống với liều $5000 \mathrm{mg} / \mathrm{kg}$. Theo dõi tình trạng của chuột cũng trong 72 giờ.62 Do cả hai chuột uống với liều $5000 \mathrm{mg} / \mathrm{kg}$ không chết nên chúng tôi chuyển sang bước tiếp theo.

2.2.2. Pha đánh giá. 40 chuột nhắt được chia ngẫu nhiên thành 4 nhóm, mỗi nhóm 10 con. Chuột trong mỗi nhóm được cho uống với một liều duy nhất trong các liều $500 \mathrm{mg} / \mathrm{kg}$, $1000 \mathrm{mg} / \mathrm{kg}, 2000 \mathrm{mg} / \mathrm{kg}$ và $5000 \mathrm{mg} / \mathrm{kg}$. Dấu hiệu nhiễm độc hoặc tỷ lệ chuột chết được theo dõi trong 7 ngày. Cũng như theo dõi cân nặng, nhiệt độ, tình trạng vận động, ăn uống của chuột trong thời gian nói trên. Kết thúc giai đoạn này, chuột được phẫu thuật và đánh giá hình ảnh đại thể và vi thể gan và thận.

\subsection{Các chỉ tiêu nghiên cứu}

- Tình trạng chung của chuột

- Các dấu hiệu nhiễm độc và tỷ lệ chuột chết

- Sự thay đổi trọng lượng trước và sau uống thuốc

- Hình ảnh mô học gan và thận

2.4. Phân tích số liệu. Tình trạng chuột chết và các dấu hiệu nhiểm độc nếu có được thống kê theo số lượng và tỷ lệ phần trăm. Sự thay đổi cân nặng được phân tích bằng thuật toán thống kê so sánh phương sai hai nhân tố có lặp. Đánh giá tình trạng độc tính với gan và thận của sản phẩm hạt cà phê xanh với gan và thận. Từ đó, xác định liều độc tính LD50.

\section{KẾT QUẢ NGHIÊN CỨU}

3.1. Tình trạng chung của chuột trước và sau uống thuốc. Trước và sau uống cao chiết thạch tùng, chuột ăn uống bình thường, vận động bình thường, lồng mượt. Chuột không có biểu hiện kích động, tấn công các con vật khác cũng như không có biểu hiện chậm chạm, li bì...

3.2. Tình trạng nhiễm độc và các tác dụng không mong muốn sau uống thuốc

Bảng 1. Các dấu hiệu nhiễm độc sau khi uống thuốc 72 giờ

\begin{tabular}{|c|c|c|c|c|}
\hline Triệu chứng Liều sử dụng & $\mathbf{5 0 0} \mathbf{m g} / \mathbf{k g}$ & $\mathbf{1 0 0 0} \mathbf{m g} / \mathbf{k g}$ & $\mathbf{2 0 0 0} \mathbf{m g} / \mathbf{k g}$ & $\mathbf{5 0 0 0} \mathbf{m g} / \mathbf{k g}$ \\
\hline Tiêu chảy & $0,00 \%$ & $0,00 \%$ & $0,00 \%$ & $0,00 \%$ \\
\hline Kích động & $0,00 \%$ & $0,00 \%$ & $0,00 \%$ & $0,00 \%$ \\
\hline Co giật & $0,00 \%$ & $0,00 \%$ & $0,00 \%$ & $0,00 \%$ \\
\hline Nôn & $0,00 \%$ & $0,00 \%$ & $0,00 \%$ & $0,00 \%$ \\
\hline Li bì & $0,00 \%$ & $0,00 \%$ & $0,00 \%$ & $0,00 \%$ \\
\hline Hôn mê & $0,00 \%$ & $0,00 \%$ & $0,00 \%$ & $0,00 \%$ \\
\hline Chết & $0,00 \%$ & $0,00 \%$ & $0,00 \%$ & $0,00 \%$ \\
\hline
\end{tabular}

Nhận xét: Bảng 1 cho thấy sau uống cao chiết hạt cà phê xanh với các liều nghiên cứu, tất cả chuột ở tất cả các nhóm liều không có bất kỳ triệu chứng nhiễm độc nào gồm tiêu chảy, kích động (vận động liên tục và cắn chuột được nhốt cùng), co giật, nôn, li bì, hôn mê, ,... Chúng tôi cũng khổng 
ghi nhận được chuột chết ở tất cả các lô được uống các liều khác nhau trong nghiên cứu này. Điều này gợi ý cao chiết hạt cà phê xanh với các liều nghiên cứu là không độc trên động vật thực nghiệm.

\subsection{Sự thay đổi trọng lượng trước và sau uống thuốc}

Bảng 2. Sư thay đổi cân nặng trước và sau uống thuốc

\begin{tabular}{|c|c|c|c|c|c|}
\hline Lô chuột & Ngày 1 & Ngày 3 & Ngày 5 & Ngày 7 & p \\
\hline $500 \mathrm{mg} / \mathrm{kg}$ & $20.85 \pm 2.24$ & $21.07 \pm 2.24$ & $21.27 \pm 2.37$ & $21.61 \pm 2.24$ & $\mathrm{p}>0,05$ \\
\hline $1000 \mathrm{mg} / \mathrm{kg}$ & $20.92 \pm 2.65$ & $21.04 \pm 2.65$ & $21.31 \pm 2.56$ & $21.53 \pm 2.59$ & $\mathrm{p}>0,05$ \\
\hline $2000 \mathrm{mg} / \mathrm{kg}$ & $20.72 \pm 2.48$ & $20.73 \pm 2.40$ & $20.78 \pm 2.39$ & $20.98 \pm 2.43$ & $\mathrm{p}>0,05$ \\
\hline $5000 \mathrm{mg} / \mathrm{kg}$ & $20.80 \pm 2.35$ & $20.70 \pm 2.27$ & $20.78 \pm 2.27$ & $20.92 \pm 2.32$ & $\mathrm{p}>0,05$ \\
\hline $\mathrm{p}$ & $\mathrm{p}>0,05$ & $\mathrm{p}>0,05$ & $\mathrm{p}>0,05$ & $\mathrm{p}>0,05$ & \\
\hline
\end{tabular}

Nhân xét: Sau uống thuốc, cân nặng của chuột ở tất cả các lô không giảm mà có xu hướng tăng cân mặ̆c dù sự khác biệt về cân nặng giữa trước và̀ sau uống cao chiết hạt cà phê xanh là không có ý nghĩa thống kê ở tất cả các nhóm chuột uống các liều cao chiết hạt cà phê khác nhau. Kết quả này cho thấy cao chiết hạt cà phê xanh ở các liều nghiên cứu không ảnh hưởng đến sự phát triển của chuột.

\subsection{Hình ảnh gan và thận}
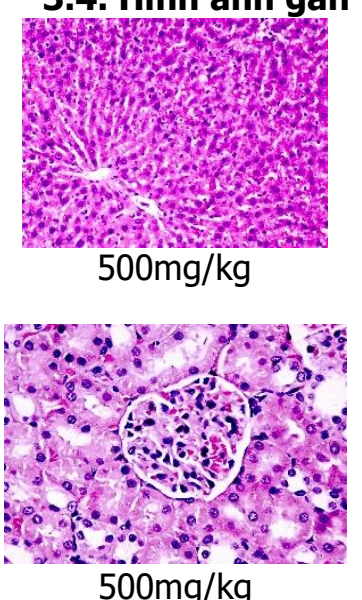

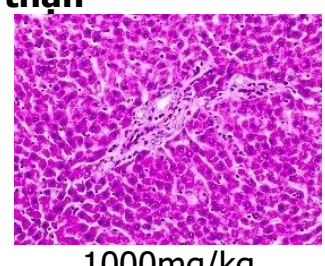

$1000 \mathrm{mg} / \mathrm{kg}$

Hình 1. Hình ảnh vi thể của gan

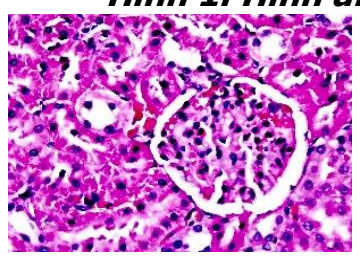

$1000 \mathrm{mg} / \mathrm{kg}$

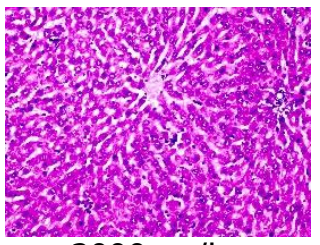

$2000 \mathrm{mg} / \mathrm{kg}$

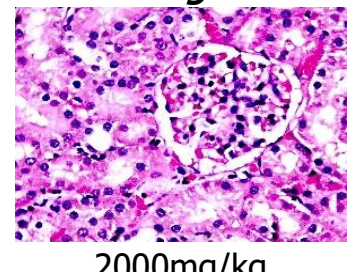

$2000 \mathrm{mg} / \mathrm{kg}$

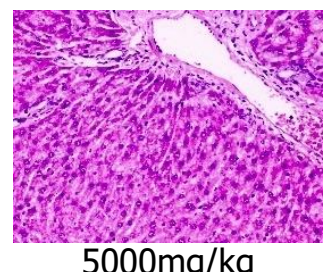

$5000 \mathrm{mg} / \mathrm{kg}$

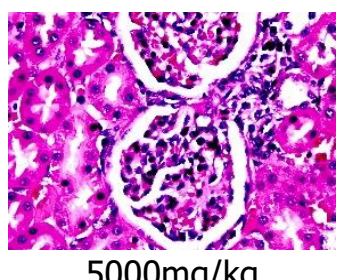

$5000 \mathrm{mg} / \mathrm{kg}$

Nhận xét: Ở tất cả các lô chuột, không có sự thay đổi cấu trúc của gan và thận trên hình ảnh mô học sau 7 ngày uống cao chiết hạt cà phê xanh.

3.5. Nhận xét về liêuu độc tính LD50. Dựa trên kết quả nghiên cứu trên cho thây ở liều dưới hoặc bằng $5000 \mathrm{mg} / \mathrm{kg}$ của cao chiết hạt cà phê xanh không có bất kỳ dấu hiệu nhiễm độc nào cũng như không làm chuột chết sau 7 ngày uống thuốc. Vì vậy, liều độc tính LD50 là lớn $5000 \mathrm{mg} / \mathrm{kg}$.

\section{BÀN LUÂNN}

Đánh giá độc tính cấp tính của dược chất là một dược liệu mới là một bước hết sức quan trọng. Đây được xem là bước đánh giá ban đâu về khả năng ứng dụng của dược chất trên lâm sàng cũng như là cở sở quan trọng để xác định liều hiệu quả sử dụng trên lâm sàng [4]. Một dược chất được khuyến cáo sử dụng trên người khi vừa có hiệu quả điều trị tốt vừa có tính an toàn cao. Vì vầy, viêc đánh giá độc tính cấp tính của cao chiết hạt cà phê xanh trong nghiên cứu này là một phần hết sức quan trọng và cần thiết.

Thông qua bước dò liêuu ban đầu với một cặp chuột được uống cùng một liều theo phương pháp tăng giảm liều được trình bày trong sách chuyên khảo gần nhất của PGS. Đố Trung Đàm (2014) [4], chúng tôi nhận thây liều $5000 \mathrm{mg} / \mathrm{kg}$ không làm chết chuột trong thời gian theo dõi là 72 ngày. Với bước dò liều này đã sơ bộ cho thấy liều độc tính LD50 nếu có là khá cao (trên $5000 \mathrm{mg} / \mathrm{kg}$ ). Nhằm tiếp tục khẳng định nhận định này, chúng tôi tiến hành trên 4 lô chuột được uống cao chiết hạt cà phê xanh với dải liều khá rộng từ $500 \mathrm{mg} / \mathrm{kg}$ đến $5000 \mathrm{mg} / \mathrm{kg}$, uống liều duy nhất và theo dõi với thời gian dài hơn là 7 ngày. Ở phần đánh giá này, chúng tôi chú ý nhiều hơn đến tình trạng chung của chuột, sự phát triển cũng như các dấu hiệu nhiễm độ̣c như co giật, li bì, hôn mê ... Đặc biệt là số chuột chết sau khi uống cao chiết hạt cà phê xanh. Cuối cùng, nhằm đưa ra bằng chứng khách quan hơn, sau thời gian theo dõi, chuột được mổ và đánh giá hình ảnh đại thể cũng như vi thể của gan và thận. Kết quả nghiên cứu của chúng tôi cho thây với dải liều cao chiết hạt cà phê xanh dưới 
$5000 \mathrm{mg} / \mathrm{kg}$ chúng tôi chưa nhận thấy có dấu hiệu nhiễm độc, chuột ăn uống bình thường và có xu hướng tăng cân, không có chuột chết trong thời gian quan sát. Đặc biệt, hình ảnh vi thể gan thận cho thấy không có sự biến đổi bất thường về cấu trúc vi thể của gan và thận. Kết quả này cho thấy cao chiết hạt cà phê xanh là an toàn với liều dưới $5000 \mathrm{mg} / \mathrm{kg}$. Liều độc tính nếu có phải lớn hơn $5000 \mathrm{mg} / \mathrm{kg}$. Theo Diener và cộng sự (1995), dược chất có liều chết trung bình LD50 trên $5000 \mathrm{mg} / \mathrm{kg}$ được cho là không độc [8]. Do đó, có thể khẳng định cao chiết hạt cà phê xanh là không độc đối với cơ thể sống. Kết quả nghiên cứu của chúng tôi là phù hợp với các nghiên cứu trước đây về độc tính của cao chiết hạt cà phê xanh trên thực nghiệm. Theo nghiên cứu của Oliveira và cộng sự (2020) cũng như nghiên cứu của Faria và cộng sự (2020) đều cho rằng liều độc tính LD50 của sản phẩm hạt cà phê xanh là khá lớn và không xác định được với liều sử dụng và thời gian quan sát thực hiện trong nghiên cứu. Hai nhóm nghiên cứu này cũng thống nhất nhận định rằng sản phẩm hạt cà phê xanh an toàn đối với cơ thể sống.

\section{KẾT LUẬN}

Nghiên cứu độc tính cấp tính cho thấy với liêu cao chiết hạt cà phê xanh dưới $5000 \mathrm{mg} / \mathrm{kg}$ không ảnh hưởng đến sự phát triển, không gây độc đối với động vật thực nghiệm. Vì vậy, cao chiết hạt cà phê xanh là an toàn. Liệu độc tính
LD50 của cao chiết hạt cà phê xanh là lớn hơn $5000 \mathrm{mg} / \mathrm{kg}$.

\section{TÀI LIÊU THAM KHẢO}

1. Centers for Disease Control and Prevention (CDC). Vital signs: prevalence, treatment, and control of high levels of low-density lipoprotein cholesterol-United States, 1999-2002 and 20052008. MMWR Morb Mortal Wkly Rep. 2011;60(4):109-114.

2. Mozaffarian D, Benjamin EJ, Go AS, et al. Heartdisease and stroke statistics-2016 update: a report from the American Heart Association. Circulation. 2016;133(4): e38-e360.

3.https: / / tuyengiao.vn/y-te-cong-dong/thuacholesterol-trong-co-the-thuc-trang-dang-baodong-o-viet-nam-hien-nay-130303

4. Đố Trung Đàm (2014). Phương pháp xác định độc tính của thuốc, Nhà xuất bản Y học, Hà Nội.

5. Bổ Y tế (2015). Hướng dẫn thử nghiếm tiền lâm sảng và lâm sang thuốc đông $\mathrm{y}$, thuốc từ dược liệu. Hà Nội, ngày 27 tháng 10 năm 2015.

6. Oliveira NA, Sandini TM, Cornelio-Santiago HP et al. Acute and subacute ( 28 days) toxicity of green coffee oil enriched with diterpenes cafestol and kahweol in rats. Regul Toxicol Pharmacol. 2020; 110:104517.

7. Faria WCS, da Silva AA, Veggi $\mathbf{N}$ et al. Acute and subacute oral toxicity assessment of dry encapsulated and non-encapsulated green coffee fruit extracts. Journal of Food and Drug Analysis. 2020; 28:143e161.

8. Diener W., Mischke U., Kayser D. and Schlede E. (1995). The Biometric Evaluation of the OECD Modified Version of the Acute-Toxic-Class Method (Oral). Arch. Toxicol. 69, 729-734.

\section{VAI TRÒ CỦA IgA, IgG và IgM HUYẾT TƯO'NG TRONG DỰ BÁO ĐÁP ÚNG ĐIỀU TRI Ở NGƯỜII LỚN MẮC HộI CHỨNG THÂ̂N HƯ NGUYÊN PHÁT}

\section{Nguyễn Thị Thu Hiền ${ }^{1}$, Phạm Văn Trân ${ }^{2}$, Lê Việt Thắng²}

\section{TÓM TẮT}

Mục tiêu: Xác địnhgiá trị dự báo không đáp ứng điều trị corticosteroid của IgA, IgG và IgM huyết tương ở người lớn mắc hội chứng thận hư (HCTH) nguyên phát. Đối tượng và phương pháp:Nghiên tiến cứu theo dõi dọctrên 57 bệnh nhân được chẩn đoán HCTH nguyên phát. Đánh giá đáp ứng điều trị dựa vào biến đối lượng protein niệu 24 giờ trong đợt điều trị. Nồng độ IgA, IgG và IgM huyết tương được xác định bằng phương pháp ELISA, tại thời điểm ngày

${ }^{1}$ Trường Cao đẳng Y tế Phú Thọ

${ }^{2}$ Bênh viên 103 , Hoc viện Quân y

Chịu trách nhiệm chính: Nguyễn Thị Thu Hiền

Email: bshienpt@gmail.com

Ngày nhận bài: $10 / 10 / 2021$

Ngày phản biên khoa học: 7/11/2021

Ngày duyệt bài: 22/11/2021 thứ 2 bệnh nhân nhâp viên. Kết quả: Sau điều tri lượng protein niệu 24 giờ trung bình giảm có ý nghĩa so với trước điều trị, p< 0,001. Có 19,4\% bệnh nhân không đáp ứng điều trị corticosteroid. Nhóm bệnh nhân không đáp ứng điều trị có nồng đô ure, creatinine máu cao hơn, mức lọc câu thận thẩp hơn nhóm bệnh nhân đáp ứng điều trị, $p<0,05$. Không có sự khác biệt về nồng độ IgA, IgG và IgM giữa nhóm đáp ứng và không đáp ứng điêu tri, $p>0,05$. Kết luận: IgA, IgG và IgM huyết tương không có giá trị dự báo đáp ứng với điều trị corticosteroid ở người lớn mắc hội chứng thận hư nguyên phát.

Từ khóa: Nồng độ IgA, IgG và IgM huyết tương, Hội chứng thận hư nguyên phát người lớn, Giá trị dự báo không đáp ứng điêu trị.

\section{SUMMARY \\ ROLE PF PLASMA IgA, IgG AND IgM LEVELS IN PREDICTION OF RESPONSE TO}

